\title{
Gas chromatographic determination of water and ethanol in silage by internal standard method
}

\section{LEA HUIDA}

\author{
Institute of Animal Husbandry, Agricultural Research Centre, 31600 \\ Jokioinen
}

\begin{abstract}
Water and ethanol contents of different silages were determined by solvent extraction gas chromatography. Methanol was used as internal standard. The gas chromatograph was equipped with thermal conductivity and hydrogen flame ionization detectors. Glass columns, length $1.5 \mathrm{~m}$, i.d. $2 \mathrm{~mm}$, were packed with Chromosorb 101, 80/100 mesh size. Water and ethanol extractions of 10 silages and gas chromatographic runs of the extracts could be carried out daily. The methods are suitable for routine laboratory analysis and use of the internal standard allows the gas chromatographic runs to be performed faster and more accurately. The precisions of water and ethanol determinations were satisfactory, the mean relative standard deviation percents of 12 replicate analyses being respectively 0.22 and 2.55 . Water content of silages was also determined by conventional forced-air oven drying at $105^{\circ} \mathrm{C}$. When ethanol content of the silage was above 5 percent, there was a tendency for water contents obtained by the oven drying method to be over 5 percentage units greater than those obtained by solvent extraction gas chromatography. When the ethanol content was below 0.5 percent, high acetic acid and lactic acid contents with low $\mathrm{pH}$ resulted the same tendency, the difference between the methods varring from 0.5 to 2.2 percentage units.
\end{abstract}

\section{Introduction}

The dry matter content of silage determined by the conventional oven drying method is often erroneous because the volatile substances of fermented feeds are evaporated together with the water. Methods for analysing water from alcohol extract of silage by titration (HOOD et al. 1971) or by gas chromatography (FENTON et al 1981) have been investigated in several laboratories. In those methods the silage is first homogenized by milling with dry ice through a screen and water is extracted from a small amount of homogenate $(4 \mathrm{~g})$ with absolute ethanol. In this study the prehandling has been simplified and water from chopped silage is extracted with absolute ethanol in a blendor, using a larger sample $(30 \mathrm{~g})$ and more solvent $(270 \mathrm{~g})$ than in previous studies. Water and ethanol, the latter extracted from silage with water, are determined simultaneously. The accuracy and speed of analysis has been enhanced by introduction of an internal standard. 
The specific weight of absolute ethanol (99.1-99.5 \% w/w) was measured before preparation of the standard solutions for ethanol determination.

Methanol (Merck p.a.), used as internal standard, was refluxed over $\mathrm{Mg}$ (turnings for Grignard reaction) for 3-4 hours and distilled. Dried methanol was stored in a tightly sealed bottle in a desiccator and apportioned to smaller quantities in tubes sealed with screw caps.

\section{Sample prehandling and preparation of standard solutions}

Chopped silage $(20-40 \mathrm{~g})$ was weighed into a blendor container $(1 \mathrm{l})$, absolute ethanol was added to the weight of $300 \mathrm{~g}$ and the container was sealed tightly. The mixture was extracted for 5-6 min in the blendor (Waring Laboratory Blendor Explosion Proof). After cooling the mixture was poured to a plastic bottle and the bottle tightly capped. After half an hour, the mixture was shaken and part of it centrifuged in a capped tube $(120 \mathrm{ml})$ at $3000 \mathrm{rpm}$ for $5 \mathrm{~min}$. An amount of $20-23 \mathrm{~g}$ of clear extract was weighed in a capped volumetric flask $(25 \mathrm{ml})$ and a volume of about $500 \mathrm{ul}$ of dry methanol was added with a Hamilton syringe (gas tight). The amounts of extract and methanol were weighed to an accuracy of $0.01 \mathrm{mg}$. The solution was stored in a desiccator until required for gas chromatographic analysis. A water standard solution of similar water and internal standard content as the sample-extracts, was prepared weekly.

For ethanol determination chopped silage was extracted twice with water in a blendor for $5 \mathrm{~min}$, with cooling in between. The cooled mixture was filtered with suction through Whatman 1 filterpaper. A volume of $30 \mu \mathrm{l}$ of dry methanol was added to the filtrate (ca. $23 \mathrm{~g}$ ) with a Hamilton syringe (50 $\mu \mathrm{l})$. The amounts of filtrate and methanol were weighed accurately.

An ethanol stock solution of $1.000 \% \mathrm{w} / \mathrm{w}$ was prepared, from which a series of ethanol standard solutions of $0.100-0.010 \% \mathrm{w} / \mathrm{w}$ were diluted to contain similar amounts of internal standard as the sample solutions.

\section{Gas chromatography}

Instrument parameters of Hewlett Packard Model 5730 A dual column gas chromatograph.

\begin{tabular}{lcc}
\hline & Water analysis & Ethanol analysis \\
\hline Columns & $\begin{array}{c}\text { Chromosorb } 101,80 / 100 \text { mesh } \\
\text { lenght } 1.5 \mathrm{~m}, \mathrm{i} . \mathrm{d} .2 \mathrm{~mm}\end{array}$ & same \\
Oven temperature & $140^{\circ} \mathrm{C}$ & same \\
Detectors & Thermal conductivity $250^{\circ} \mathrm{C}$ & Hydrogen flame ionization $300^{\circ} \mathrm{C}$ \\
Injector temperature & $250^{\circ} \mathrm{C}$ & same \\
Carrier gas flow rate & helium $30 \mathrm{ml} / \mathrm{min}$ & helium $22 \mathrm{ml} / \mathrm{min}$ \\
Injection volume & about $2 \mu \mathrm{l}$ & about $1 \mu \mathrm{l}$ \\
Hewlett Packard & Model $3380 \mathrm{~A}$ & Model $3390 \mathrm{~A}$ \\
integrators & &
\end{tabular}


The gas chromatographic runs of water and ethanol extracts were carried out simultaneously. The separation is shown in Figures 1 and 2.

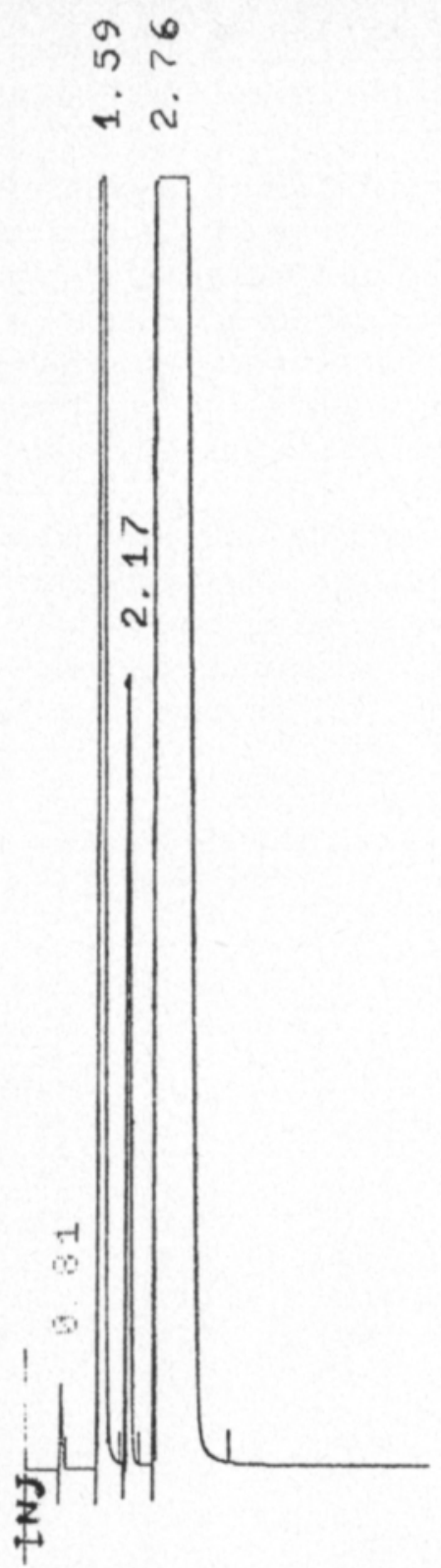

Figure 1. Gas chromatogram of water analysis: water (1.59), methanol, internal standard (2.17) and ethanol, solvent (2.76).

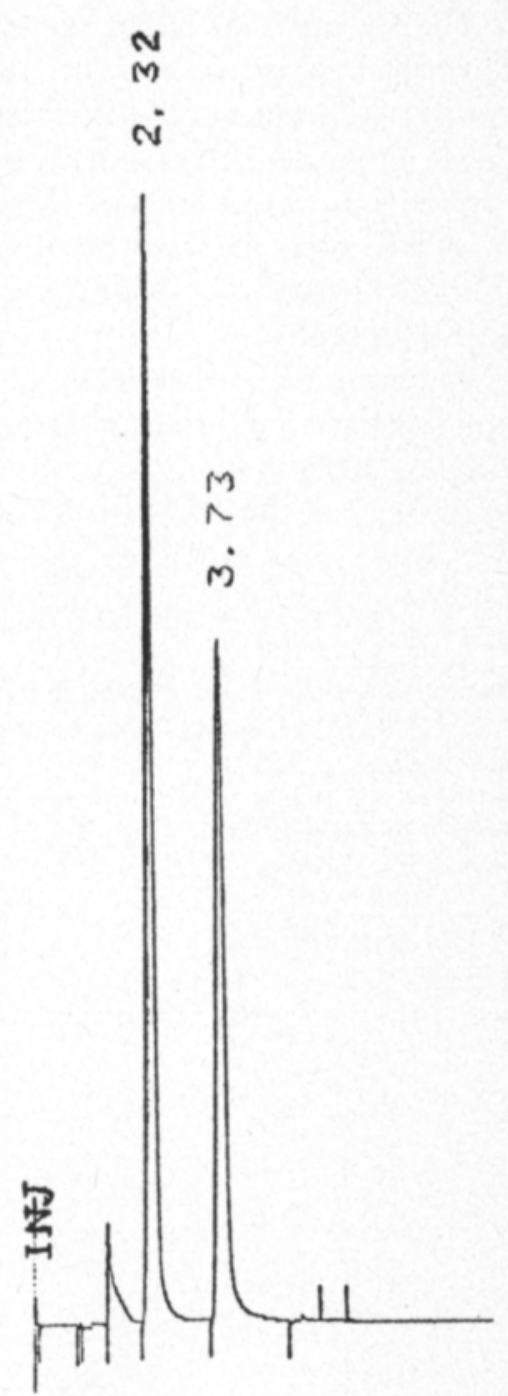

Figure 2. Gas chromatogram of ethanol analysis: methanol, internal standard (2.32) and ethanol (3.73).

\section{Results and discussion}

The decision to use methanol as internal standard was based on its nonappearance in silage extracts and favorable position in the gas chromato- 
graphic run. The water standard solution was injected 3-4 times before calibration of the integrator for water measurement, until the RWR-value* (relative weight response) showed reproduciple accuracy. Table 1 shows the variation of RWR during one week of water analysis and the difference in the results of replicate analyses made of 13 different sample-extracts on successive days.

The variation of RWR increased if the water standard solution was not prepared weekly. It was also found necessary to inject absolute ethanol between different sample-extracts to avoid absorbed water from the precious sample injection. Occasionally instability was avoided by installing a new septum in the injection port. After a pause of one hour between sample runs, the RWR was checked by injecting water standard solution. The small standard deviation of water contents indicates satisfactory precision of gas chromatography.

Since the ethanol content of silages was variable, calibration was made with standard solutions of different concentration. The calibrations were stored in method memories of a Hewlett Packard intergrator Model 3390 A and as needed, the calibration corresponding to the ethanol concentration of the sample was taken to the working area. The reproducibility of the

Table 1. The weekly variation of RWR in water analysis and water contents of silages, standard deviations and relative standard deviations of the results obtained on successive days for the same silageextract.

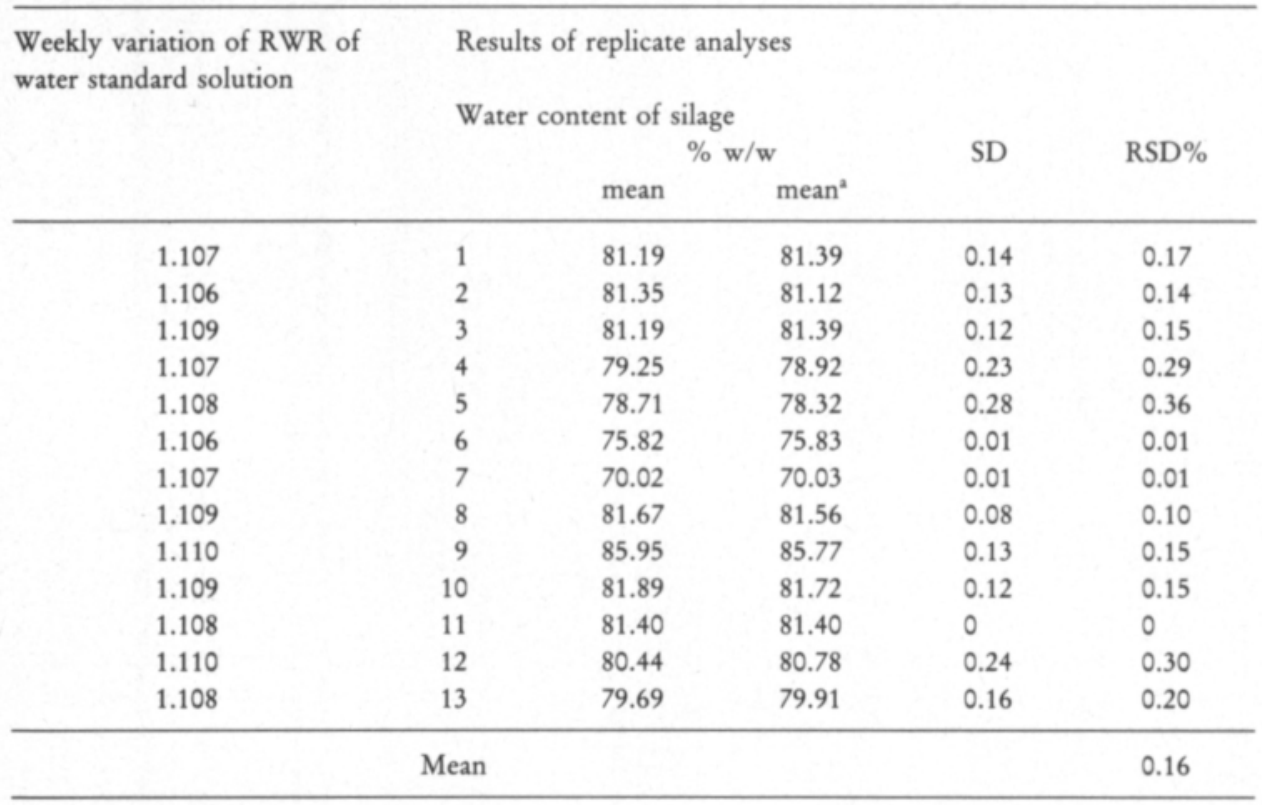

a) The mean of two injections.

RWR $=\frac{\frac{\text { *area of water peak }}{\text { weight of water }}}{\frac{\text { area of methanol peak }}{\text { weight of methanol }}}$ 
Table 2 Weekly variation of RWR in ethanol analysis and ethanol contents of silages and standard deviations of the results obtained on successive days for the same silage-extract.

Weekly variation of RWR of

3 ethanol standard solutions.

\begin{tabular}{|c|c|c|c|c|c|c|}
\hline \multicolumn{2}{|c|}{ Ethanol content } & W/W & \multicolumn{3}{|c|}{ Ethanol content of silage } & \multirow{3}{*}{ SD } \\
\hline 0.008 & 0.020 & 0.098 & & \multicolumn{2}{|c|}{$\% \mathrm{w} / \mathrm{w}$} & \\
\hline RWR & RWR & RWR & & mean & mean ${ }^{2)}$ & \\
\hline 1.37 & 1.36 & 1.37 & 1 & 0.70 & 0.69 & 0.007 \\
\hline 1.37 & 1.36 & 1.37 & 2 & 0.08 & 0.08 & 0 \\
\hline 1.36 & 1.37 & 1.37 & 3 & 0.12 & 0.11 & 0.007 \\
\hline 1.36 & 1.36 & 1.36 & 4 & 0.23 & 0.23 & 0 \\
\hline 1.36 & 1.37 & 1.38 & 5 & 0.15 & 0.15 & 0 \\
\hline 1.38 & 1.36 & 1.38 & 6 & 0.55 & 0.55 & 0 \\
\hline 1.39 & 1.35 & 1.36 & 7 & 0.49 & 0.49 & 0 \\
\hline 1.38 & 1.36 & 1.37 & 8 & 0.11 & 0.12 & 0.007 \\
\hline 1.38 & 1.36 & 1.37 & 9 & 0.12 & 0.13 & 0.007 \\
\hline 1.37 & 1.38 & 1.37 & 10 & 0.34 & 0.33 & 0.007 \\
\hline
\end{tabular}

a) The mean of two injections.

Table 3 Reproducibility of the silage extraction in water and ethanol measurement.

\begin{tabular}{|c|c|c|c|c|c|c|c|}
\hline \multicolumn{2}{|c|}{$\begin{array}{l}\text { Water content of } \\
\text { silage }\end{array}$} & \multirow[b]{2}{*}{ SD } & \multirow[b]{2}{*}{ RSD \% } & \multicolumn{2}{|c|}{$\begin{array}{l}\text { Ethanol content of } \\
\text { silage }\end{array}$} & \multirow[b]{2}{*}{ SD } & \multirow[b]{2}{*}{ RSD \% } \\
\hline & $\% \mathbf{w} / \mathbf{w}$ & & & & $\% \mathbf{w} / \mathbf{w}$ & & \\
\hline 1 a & 74.68 & 0.09 & 0.12 & 1 a & 0.07 & 0.01 & 9.4 \\
\hline b & 74.55 & & & b & 0.08 & & \\
\hline $2 a$ & 78.78 & 0.16 & 0.20 & $2 a$ & 0.34 & 0.01 & 4.3 \\
\hline b & 78.56 & & & b & 0.32 & & \\
\hline $3 a$ & 78.39 & 0.04 & 0.04 & $3 a$ & 0.27 & 0.01 & 5.1 \\
\hline b & 78.34 & & & b & 0.29 & & \\
\hline $4 \mathrm{a}$ & 75.61 & 0.02 & 0.03 & $4 a$ & 0.31 & 0 & 0 \\
\hline b & 75.58 & & & b & 0.31 & & \\
\hline 5 a & 72.95 & 0.19 & 0.26 & 5 a & 0.32 & 0.01 & 2.2 \\
\hline b & 73.22 & & & b & 0.31 & & \\
\hline $6 a$ & 73.92 & 0.28 & 0.37 & $6 a$ & 0.41 & 0 & 0 \\
\hline b & 73.53 & & & b & 0.41 & & \\
\hline $7 a$ & 71.85 & 0.48 & 0.67 & $7 a$ & 0.21 & 0 & 0 \\
\hline b & 71.17 & & & b & 0.21 & & \\
\hline $8 a$ & 77.32 & 0.03 & 0.05 & $8 a$ & 0.27 & 0.01 & 5.4 \\
\hline b & 77.38 & & & b & 0.25 & & \\
\hline $9 a$ & 76.38 & 0.09 & 0.12 & $9 \mathrm{a}$ & 0.27 & 0 & 0 \\
\hline b & 76.25 & & & b & 0.27 & & \\
\hline $10 \mathrm{a}$ & 77.99 & 0.08 & 0.10 & $10 \mathrm{a}$ & 0.38 & 0 & 0 \\
\hline b & 77.88 & & & b & 0.38 & & \\
\hline $11 \mathrm{a}$ & 75.54 & 0.03 & 0.04 & $11 \mathrm{a}$ & 0.42 & 0.01 & 1.7 \\
\hline b & 75.58 & & & b & 0.43 & & \\
\hline $12 \mathrm{a}$ & 72.04 & 0.42 & 0.59 & & & & \\
\hline b & 71.44 & & & & & & \\
\hline Mean & & & 0.22 & & & & 2.55 \\
\hline
\end{tabular}

Results of replicate analyses

SD

0.007

0.007

0.007
Ethanol content of silage 
calibration was checked daily with the corresponding ethanol standard. Table 2 shows the variation of RWR of three ethanol standard solutions during a week and the difference between the results of replicate analyses made of 10 different sample-extracts on successive days.

The ethanol content of silages was mostly so low that the variation of RWR did not influence the results. Standard deviations of ethanol contents were small showing the satisfactory precision of gas chromatography.

The precision of water and ethanol measurements was also studied by repeating the extraction of the same silage twice (Table 3 ).

The small standard deviation indicates satisfactory reproducibility of the extraction procedure.

The results of water determination obtained by solvent extraction gas chromatography and conventional forced-air oven drying were compared for 28 silages. The figures are reported in Table 4.

Table 4. The chemical composition of 28 silages and their water content as determined by oven drying and solvent extraction gas chromatography.

\begin{tabular}{|c|c|c|c|c|c|c|c|c|}
\hline \multirow[t]{2}{*}{ Silage } & \multicolumn{3}{|c|}{ Amount of water $\%$} & \multicolumn{4}{|c|}{ Amount of volatile substances $\%$} & \multirow[t]{2}{*}{$\mathrm{pH}$} \\
\hline & $105^{\circ} \mathrm{C}$ & GC & Difference & Ethanol & $\begin{array}{l}\text { Acetic } \\
\text { acid }\end{array}$ & $\begin{array}{l}\text { Lactic } \\
\text { acid }\end{array}$ & $\mathrm{NH}_{5}-\mathrm{N}$ & \\
\hline Whole cereal & 76.40 & 73.03 & 3.37 & 0.84 & 0.74 & 0.74 & 0.53 & 5.7 \\
\hline " & 76.20 & 73.93 & 2.27 & 0.80 & 1.04 & 0.47 & 0.81 & 7.5 \\
\hline$n$ & 75.30 & 73.07 & 2.23 & 0.52 & 0.97 & 1.09 & 0.48 & 5.7 \\
\hline$"$ & 74.35 & 72.14 & 2.21 & 0.65 & 0.88 & 0.70 & 0.81 & 8.2 \\
\hline$n$ & 75.05 & 73.00 & 2.05 & 0.60 & 1.00 & 0.58 & 0.51 & 6.0 \\
\hline 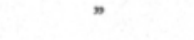 & 72.07 & 70.52 & 1.55 & 0.51 & 1.40 & 0.19 & 0.75 & 6.8 \\
\hline$n$ & 70.05 & 68.56 & 1.49 & 0.28 & 1.44 & 0.29 & 0.81 & 7.8 \\
\hline$m$ & 72.60 & 72.21 & 0.39 & 0.10 & 0.82 & 0.25 & 0.15 & 8.3 \\
\hline Beet plus beet & 92.96 & 85.70 & 7.26 & 6.49 & 0.15 & 0.21 & 0 & 4.4 \\
\hline leaves & 92.90 & 85.67 & 7.23 & 8.01 & 0.07 & 0.16 & 0 & 4.4 \\
\hline " & 89.98 & 84.33 & 5.65 & 5.59 & 0.22 & 0.41 & 0 & 4.3 \\
\hline$n$ & 92.70 & 89.18 & 3.52 & 3.12 & 0.29 & 0.79 & 0.01 & 4.9 \\
\hline$n$ & 90.41 & 87.82 & 2.59 & 2.65 & 0.36 & 1.00 & 0.01 & 4.6 \\
\hline$"$ & 89.73 & 87.40 & 2.33 & 2.17 & 0.41 & 1.05 & 0.02 & 4.2 \\
\hline$"$ & 87.48 & 86.90 & 0.58 & 0.21 & 0.42 & 1.36 & 0.02 & 4.8 \\
\hline$n$ & 86.96 & 86.76 & 0.21 & 0.27 & 0.44 & 1.29 & 0.03 & 4.4 \\
\hline " & 87.27 & 87.15 & 0.12 & 0.38 & 0.34 & 1.09 & 0.02 & 4.4 \\
\hline Grass silage & 82.30 & 80.28 & 2.02 & 0.04 & 0.50 & 2.20 & 0.02 & 4.0 \\
\hline$n$ & 84.72 & 82.47 & 2.25 & 0.06 & 0.53 & 2.10 & 0.03 & 4.0 \\
\hline$"$ & 78.47 & 76.53 & 1.94 & 0.57 & 0.61 & 1.20 & 0.07 & 3.9 \\
\hline$n$ & 80.12 & 78.45 & 1.67 & 0.48 & 0.70 & 1.20 & 0.07 & 4.2 \\
\hline$"$ & 83.65 & 82.15 & 1.50 & 0.07 & 0.51 & 2.20 & 0.04 & 4.0 \\
\hline$"$ & 79.50 & 78.22 & 1.28 & 0.32 & 0.61 & 1.40 & 0.05 & 4.4 \\
\hline$"$ & 82.60 & 81.73 & 1.21 & 0.05 & 0.42 & 2.30 & 0.04 & 4.0 \\
\hline$n$ & 82.52 & 81.39 & 1.13 & 0.04 & 0.33 & 2.30 & 0.05 & 4.0 \\
\hline$n$ & 79.95 & 79.00 & 0.95 & 0.10 & 0.69 & 1.30 & 0.04 & 4.0 \\
\hline$"$ & 78.87 & 78.49 & 0.38 & 0.23 & 0.45 & 1.70 & 0.02 & 3.9 \\
\hline$n$ & 83.82 & 83.45 & 0.37 & 0.03 & 0.23 & 1.10 & 0.02 & 3.9 \\
\hline
\end{tabular}


As the table shows when the ethanol content of silage increased over 5 percent, there was a tendency for the water contents to be over 5 percentage units greater with the oven drying method than with solvent extraction gas chromatography. When the ethanol content was below 0.5 percent, the volatilization of lactic acid and acetic acid during oven drying, especially when the acid contents were high and $\mathrm{pH}$ was low, resulted in the same tendency, the difference between the methods vaying from 0.5 to 2.2 percentage units.

\section{References}

HOOD, R. L., ALLEN, C. E., GOODRICH, R. D. and MEISKE, J. C. 1971. A rapid method for the direct chemical determination of water in fermented feeds. J. Anim. Sci. 33, (6), 1310-1314.

FENTON, T. W., FENTON, M. and MATHISON, G. W. 1981. Determination of water in fermented feeds by gas chromatography. Can. J. Anim. Sci. 61, 827-831.

Ms received May 25, 1982

\section{SELOSTUS}

\section{Veden ja alkoholin määrittäminen säilörehusta kaasukromatografisesti sisäisen standardin menetelmällä.}

\section{Lea Huida}

\section{Kotieläinhoidon tutkimuslaitos, Maatalouden tutkimuskeskus 31600 Jokioinen}

Erilaisten säilörehujen vesi- ja alkoholipitoisuudet määritettiin kaasukromatografisesti liuotinekstraktista. Metanolia käytettiin sisäisenä standardina. Kaasukromatografi oli varustettu kuumalanka- ja vetyliekki-ionisaatiodetektoreilla. Lasikolonnit, joiden pituus oli $1.5 \mathrm{~m}$, sis. $\varnothing 2 \mathrm{~mm}$, pakattiin täytemateriaalilla Chromosorb 101, 80/100 messiä. Päivittäin voitiin tehdä 10 säilörehun uutot alkoholilla ja vedellä sekä ekstraktien kaasukromatografiset ajot. Menetelmät soveltuvat rutiinianalyyseiksi ja käyttämällä sisäistä standardia kaasukromatografista ajoa voidaan nopeuttaa ja tarkentaa. Veden ja etanolin määrityksen tarkkuus oli tyydyttävä, 12 toistoanalyysin keskimääräisen suhteellisen standardipoikkeamaprosentin ollessa vastaavasti 0.22 ja 2.55. Säilörehun kosteus märitettiin myös tavallisella uunikuivausmenetelmällä $105^{\circ} \mathrm{C}$ :ssa, jolla saatiin jopa 5 prosenttiyksikköä suurempia vesipitoisuuksia kuin kaasukromatografisella menetelmällä silloin, kun säilörehujen alkoholipitoisuus nousi yli 5 prosentin. Kun alkoholipitoisuus laski alle 0.5 prosentin aiheutti korkea etikkahappo- ja maitohappopitoisuus tuloksissa samansuuntaisen tendenssin, menetelmien välisen eron vaihdellessa $0.5-2.2$ prosenttiyksikköön. 